УДК 347.626.2

\title{
ОСОБЕННОСТИ ПРАВОВОГО РЕГУЛИРОВАНИЯ ИНСТИТУТА БРАЧНОГО ДОГОВОРА В РОССИИ И ЗА РУБЕЖОМ
}

\author{
Скачкова Ольга Сергеевна \\ к.ю.н., доцент
}

Кутовой Ян Сергеевич

Рябова Инна Сергеевна

кафедра гражданского и арбитражного процесса СГЭУ

Аннотация: В статье рассматриваются основные аспекты правового регулирования института брачного договора в России и за рубежом, автором выделены особенности развития, проблемы и причин роста популярности. В последнее десятилетие наблюдается уверенный рост числа заключаемых брачных договоров российскими гражданами. Вместе с тем, конструкция его несовершенна, имеются некоторые законодательные пробелы. Одним из способов решения данной проблемы следует считать заимствование норм, регулирующих институт брачного договора, из зарубежного права. В целях решения вышеуказанной проблемы, в статье проведен сравнительный анализ некоторых аспектов правового института брачного договора США, стран Европейского союза и СНГ с российским брачным договором.

Ключевые слова: брачный договор, институт брака, правовое регулирование, российский и зарубежный опыт.

\section{FEATURES OF THE LEGAL REGULATION OF THE INSTITUTION OF THE MARRIAGE CONTRACT IN RUSSIA AND ABROAD}

\section{Skachkova Olga Sergeevna Kutovoy Yan Sergeevich Ryabova Inna Sergeevna}

\begin{abstract}
The article deals with the main aspects of the legal regulation of the institution of the marriage contract in Russia and abroad, the author highlights the features of the development, problems and reasons for the growth of popularity. In the last decade, there has been a steady increase in the number of marriage contracts
\end{abstract}


concluded by Russian citizens. At the same time, its design is imperfect, there are some legislative gaps. One of the ways to solve this problem should be considered borrowing the rules governing the institution of the marriage contract from foreign law. In order to solve the above problem, the article provides a comparative analysis of some aspects of the legal institution of the marriage contract of the United States, the European Union and the CIS countries with the Russian marriage contract.

Key words: prenuptial agreement, institution of marriage, legal regulation, Russian and foreign experience.

Понятие барачного договора не является новой идеей ни с юридической, ни с культурной точки зрения. Женщины хотели получить заверения в том, что в случае развода или смерти супруга они не останутся бездомными, по крайней мере, с египетских времен более 2000 лет назад.

Брачный договор - это юридически обязательные контракты, подписанные между супругами перед обменом брачными клятвами, которые защищают каждую сторону от неоправданных потерь в случае развода, смерти или других непредвиденных обстоятельств, которые могут повлиять на финансовое благополучие пары. По сути, этот нотариально заверенный документ определяет, как пара будет справляться с финансовыми аспектами своего брака, и, хотя на законных основаниях он существует уже тысячи лет, законы, регулирующие брачные соглашения, претерпели изменения, особенно в последние годы.

Для России брачный договор приходится довольно новым явлением. С принятием в 1995 году СК РФ было положено начало развитию законодательного урегулирования и действия брачного договора в нашей стране, что повлекло за собой необходимость введения коллизионной нормы о брачном договоре [1].

Спорные вопросы института брачного договора на международном уровне регулируются сравнительно небольшим количеством конвенций. Ведущей в данной сфере, является Конвенция о праве, применимом к режиму собственности супругов 1978 года (далее Гаагская конвенция 1978 г.), исходя из положений которой, можно сделать выводы, что режим собственности регулируется правом той страны, которое будущие супруги определяют перед вступлением в брак [2, с. 694]. Это говорит о том, что им предоставляется возможность выбора права, которым будет регулироваться их собственность. Данное положение безусловно основано на принципе автономии воли сторон, однако такая воля несколько ограничена, так как необходимо выбирать только из 
прав, предложенных настоящей конвенцией. Однако говорить о существенных ограничениях не приходится, поскольку граждане могут выбрать.

В первое десятилетие после легализации в Российской Федерации брачного договора, насчитывалось гораздо меньшее количество семейных пар, желающих заключить данный договор. Это, в первую очередь, было связано с тем, что менталитет россиян постсоветского периода корнями уходит в эпоху Советского Союза, где коммунистические и социалистические настроения негативно рассматривали частную собственность. Помимо этого, брачные договоры активно применялись в Соединенных Штатах Америки и ряде Европейских стран, а для большинства граждан постсоветского пространства, практика в заимствовании привычек запада расценивалась неодобрительно. Так же, в этом вопросе следует согласиться с мнением С.Ю. Филиппова и Ю.В. Никоноровой, которые считают, что «представление о брачном договоре у большинства российских граждан все еще носит негативный характер и многими воспринимается как некая программа на будущее его расторжение или же считается проявлением недоверия к супругу» $[9,77]$.

Фактом легального закрепления института брачного договора в Российском праве считается дата вступления в законную силу первой части Гражданского кодекса Российской Федерации (далее - ГК РФ) [2]. Таким образом, в части 1 статьи 256 ГК РФ было установлено, что супруги имеют право устанавливать договорной режим имущественных отношений. Позже, Семейный кодекс Российской Федерации (далее конкретизировал данную норму, введя понятие «брачный договор».

Статьей 40 СК РФ установлено, что брачным договором признается соглашение лиц, вступающих в брак или соглашение супругов, определяющее имущественные права и обязанности супругов в браке и (или) в случае его расторжения. Брачный договор может быть заключен как супругами, так и гражданами, вступающими в брак, однако в таком случае он вступает в законную силу только после заключения брака. Целью брачного договора является изменение установленного законом режима совместной собственности на все имущество супругов, на его отдельные виды или на имущество каждого из супругов.

Возникает вопрос, с чем связан рост популярности данного института права, и какие особенности он имеет в России? Отвечая на данный вопрос, следует рассмотреть основные причины заключения брачных договоров в нашей стране. 
Одной из них следует считать рост ипотечного кредитования с целью приобретения молодыми супружескими парами жилых помещений. Так, по данным официального интернет-портала Центрального банка России, в 2019 году было предоставлено 1287797 ипотечных кредитов [6].

Таким образом, если один из супругов, в соответствии с условиями брачного договора, берет на себя обязательства по выплате денежных средств по кредиту, то этот супруг и будет являться владельцем квартиры, что в свою очередь упростит порядок предоставления ипотечного кредита, если у одного из супругов уже имеются другие кредиты, либо у одного из супругов сложилась плохая кредитная история. Так же, в этом вопросе следует согласиться с мнением Н.Г. Асатрян и Т.А. Мосиенко, которые считают, что «для заемщика такая ситуация выглядит более достоверной, а для банка более отчетливой и удобной» $[1,300]$.

На официальных интернет сайтах крупнейших Российских банков, таких как «Сбербанк» (ПАО «Сбербанк») и «ВТБ» (ПАО «ВТБ»), представлены образцы брачных договоров, условия которых специально нацелены на упрощение процедуры получения супругами ипотечного кредита. Основным пунктом таких договоров является установление режима раздельной собственности на имущество супругов, в том числе в отношении недвижимости. Из этого следует, что исполнение договора ипотечного кредита формально ложится на плечи одного из супругов, что, как указывалось выше, является более удобным для банка.

Немаловажной причиной заключения брачного договора можно считать факт вступления в брак одним или обоими супругами во второй раз. Так, по данным интернет-портала Федеральной службы государственной статистики, в 2019 году было расторгнуто 65,3\% браков [4]. Если первый брак для одного из супругов закончился разводом, в результате которого, на основании законного режима имущества супругов, он потерял часть имущества, приобретенного хоть и во время нахождения в браке, но фактически за средства одного из супругов, то вступая во второй брак, некоторые лица становятся сторонниками брачного договора.

Помимо этого, не идет на спад активность лиц, которые вступают в брак, как правило с состоятельными гражданами, с целью дальнейшего расторжения брака и получения законной половины имущества, приобретенного супругами в период совместной жизни. В быту данная категория граждан получила название «брачные аферисты». Именно этот факт 
определил большую популярность заключения брачных договоров среди граждан с высоким уровнем дохода, целью которого является ограждение их имущества от деятельности брачных аферистов.

Считается, что мода на заключение брачных договоров пришла в нашу страну из зарубежных стран, таких как США и некоторых стран Европейского союза.

Только в 21 веке брачный договор превратился в более справедливое соглашение с новым законодательством, регулирующим порядок ведения брачных отношений в каждом штате в Соединенных Штатах. По состоянию на 2017 год около половины штатов Америки подписали Закон о едином добрачном соглашении, который устанавливает единые правила толкования брачных соглашений в гражданском суде.

В любом случае, для того чтобы брачный договор был признан законным судами США, должны соблюдаться определенные условия:

- соглашение должно быть заключено в письменной форме;

- он должен быть выполнен добровольно; это должно быть полное и справедливое раскрытие всех финансовых активов во время исполнения;

- это не может быть бессовестным; и он должен быть оформлен обеими сторонами «в порядке, требуемом для записи дела» или подтверждения у нотариуса.

Однако, российский брачный договор имеет существенные отличия от заграничных брачных контрактов, которые имеют как положительный, так и отрицательный характер. Так, например, в США брачный договор может регулировать помимо имущественных, еще и личные неимущественные отношения супругов.

Таким образом, брачный договор в США может обязать супругов, например, любить друг друга или хранить супружескую верность. Российское законодательство противоречит этой норме, установив пунктом 3 статьи 42 СК РФ, что брачный договор не может регулировать личные неимущественные отношения между супругами. Однако, по мнению П.В. Алексия и И.В. Петрова «имущественные отношения супругов могут быть поставлены в зависимость от наступления или не наступления определенных условий неимущественного характера» $[7,151]$.

В соответствии с Германским гражданским законодательством, брачный договор заключается в письменной форме в присутствие нотариуса и сторон [5]. Такой договор может быть заключен как до вступления в брак, так и в 


\section{ВСЕРОССИЙСКИЙ ФОРУМ МОЛОДЫХ ИССЛЕДОВАТЕЛЕЙ}

любой момент в период брака, что является аналогичным нашему отечественному законодательству. В нем можно предусмотреть положения, касающиеся изменения отдельных пунктов договора, регламентацию обязанностей, связанных с содержанием одного из супругов после расторжения брака и другие.

Правовое регулирование института брачного договор во Франции значительного отличается от Российского. Так, например, основной особенностью французского законодательства в отношении регулирования института брачного договора является, во-первых, возможность его заключения через институт представительства, это прямо прописано в ФГК, в то время как в отечественном законодательстве прямого запрета на заключение брачного договора по доверенности нет, но и никакого закрепления нормы о такой возможности также нет. Во-вторых, существуют различия по поводу порядка изменения содержания брачного договора. Данный порядок во Франции довольно консервативен, так в соответствии со ст. 1397 ФГК после заключения брака внести изменения в брачный договор можно, но лишь по истечении двухлетнего срока супружества. Причем внести изменения по прошествии такого срока можно только в судебном порядке [6, с. 387]. Российское законодательство в этом смысле более демократично, поскольку не ограничивает порядок изменения каким-либо сроком и совершается в форме соглашения супругов во внесудебной процедуре.

Таким образом, исходя из данного мнения, можно предположить, что в брачном договоре можно, например, указать условие, в результате которого супруг, совершивший супружескую измену, будет обязан уплатить супруге, в качестве моральной компенсации, денежную сумму в размере одного миллиона рублей.

Однако, как показывает судебная практика, пункты такого характера в брачном договоре признаются незаконными. Так, определением Судебной коллегии по гражданским делам Верховного Суда РФ от 20 декабря 2016 г. № 5-КГ16-174, по иску гражданина «С» к гражданке «К» о признании брачного договора недействительным ввиду нахождения в нем условий о том, что в случае расторжения брака по инициативе гражданина «С», либо в результате его недостойного поведения (супружеской измены, пьянства, хулиганских действий и т.п.) имущество, нажитое во время брака и относящееся к общей совместной собственности супругов, переходит в собственность гражданки 
«К». В результате, разрешая спор и удовлетворяя исковые требования гражданина «С», суд первой инстанции исходил из того, что условия брачного договора поставили гражданина «С» в крайне неблагоприятное положение, поскольку после расторжения брака он лишается всего совместно нажитого имущества. Суд апелляционной инстанции согласился с выводами суда первой инстанции. Судебная коллегия по гражданским делам Верховного Суда Российской Федерации нашла правильными выводы судов первой и апелляционной инстанций [3].

Таким образом, можно сделать вывод, что в брачном договоре могут содержаться условия, в результате которых имущественные отношения супругов могут быть поставлены в зависимость от наступления определенных условий неимущественного характера, однако данная практика не нашла одобрения со стороны органов судебной власти.

Различия в брачных договорах разных стран имеется и в определении порядка отношений с детьми. Так, пунктом 3 статьи 42 СК РФ установлено, что брачный договор не может регулировать права и обязанности супругов в отношении детей. Напротив, законодательством Республики Беларусь установлено, что их брачный договор может регламентировать формы и методы воспитания совместных детей, а также порядок общения с ними родителя, проживающего отдельно от детей по причине расторжения брака.

Законодательство Российской Федерации в области порядка заключения брачного договора, помимо положительных сторон, имеет и ряд пробелов. Так, актуальным остается вопрос о заключении брачного договора лицами, вступающими в брак, но не достигшими брачного возраста на основании пункта 2 статьи 13 СК РФ. В данном вопросе мнения ученых расходятся. Некоторые из них считают, что брачный договор несовершеннолетние лица, вступающие в брак, могут заключить через законных представителей.

Кроме того, актуальным остается вопрос, касаемо того, что промежуток времени между заключением брачного договора до официальной регистрации брака законодательством не определен. По мнению ученных Н.Г. Асатрян и Т.А. Мосиенко «это приводит к тому, что один из супругов не спешит официально заключать брак, и брачный договор становится мертвой конструкцией, которая не влечет никаких последствий» [1, 302]. Данный вопрос нуждается в регулировании по аналогии с зарубежным законодательством, где сроки заключения брачного договора, как правило, строго определены. 
Подводя итоги, можно сделать вывод, что институт брачного договора в России развивается хоть и не быстрыми, но уверенными шагами. Однако, его развитие должно сопровождаться и грамотным законным регулированием. Определенную пользу в вопросе правового регулирования пробелов института брачного договора, может принести заимствование норм из законодательства зарубежных стран, положительно влияющих на развитие данного правового института и не противоречащих основным моральным и правовым началам семьи и брака в нашей стране.

\section{Список литературы}

1. Асатрян Н.Г., Мосиенко Т.А. Правовое регулирование института брака в международном частном праве // Научный вектор: сборник научных трудов магистров. Вып. 4. - Ростов н/Д, 2018. - С. 298 - 303.

2. Гражданский кодекс Российской федерации (часть первая) от 30.11.1994 № 51-Ф3, (ред. от 16.12.2019). // Российская газета: 08 февраля 1994 г. № $238-239$.

3. Определение Судебной коллегии по гражданским делам Верховного Суда РФ от 20 декабря 2016 г. № 5-КГ16-174. // Справочно-правовая система «Гарант» (дата обращения: 18.06.2020).

4. Официальный интергнет-портал Федеральной службы государственной статистики. [Электронный pecypc] - URL: https://www.gks.ru/folder/12781. (дата обращения: 18.06.2020

5. Официальный интергнет-сайт Федеральной нотариальной палаты. Статья «Популярность брачных договоров в России продолжает расти». [Электронный ресурс] - URL: https://notariat.ru/ru-ru/news/otvetstvennyjpodhodpopulyarnost-brachnyh-dogovorov-v-rossii-prodolzhaet-rasti. (дата обращения: 17.06.2020).

6. Официальный интернет-портал Центрального банка России. Показатели рынка ипотечного жилищного кредитования. [Электронный pecypc] - URL: https://cbr.ru/statistics/bank_sector/mortgage/ (дата обращения: 17.06.2020).

7. Семейное право: Учебник / Под ред. П.В. Алексия, И.В. Петрова. - М.: ЮНИТИ-ДИАНА: Закон и право, 2017. - 319 с.

8. Семейный кодекс Российской Федерации от 29.12.1995 № 223-Ф3 (ред. от 06.02.2020) // Российская газета. 27.01.1996. № 17.

(C) О.С. Скачкова, Я.С. Кутовой, И.С. Рябова, 2021 